station was referred to the Food and Agriculture Organization; an industrial information unit put in touch with the Department of Scientific and Industrial Research; a chemistry department with the Gmelin Institut für Anorganische Chemie; and a government agency with the International Organization for Standardization. Such liaison has been essential, for, through it, has been created a broader footing for scientific and technical documentation; in the terms of Technical Assistance, "the activity started on the right lines". LuCIA MOHOLY

\section{LATERITES AND BAUXITES OF ANTRIM}

T

HE first memoir to be published by the Geological Survey of Northern Ireland*, prepared by Mr. Y. A. Eyles and other workers, will be widely recognized as a contribution to the geochemistry and mineralogy of laterite and bauxite of outstanding importance and permanent value. Equally welcome will be the promised companion volume on the detailed geology of these rocks as they occur in the Interbasaltic Horizon of Co. Antrim. The present work deals with the nature of the chemical changes concerned in the process of lateritization and of the composition of the Interbasaltic lateritic rocks themselves. The latter were formed during a prolonged pause in the Tertiary volcanic activity responsible for the Antrim basalts. At an early stage in this Interbasaltic period there was a brief recrudescence of activity characterized by the eruption of highly silicic lavas. Intense erosion followed, with removal of most of the rhyolites and complementary deposition of thin sediments largely composed of rhyolitic debris. Towards the end of the lateritization period a thin coal seam was formed from the vegetation that flourished over the area. An interesting note records that Dr. J. B. Simpson finds the floral remains from a coal associated with bauxite near Portrush to be of essentially the same age as the corresponding horizon in Mull, to which he is inclined to ascribe a late Miocene or early Pliocene age. This is so much later than has hitherto been thought probable that the publication of Dr. Simpson's palæobotanical researches will be eagerly awaited. The Interbasaltic period was terminated by the outpouring of the Giant's Causeway and later basaltic flows. At the same time, or later, basaltic dykes were intruded, and these, cutting through the lateritic rocks, effected marked metamorphic changes.

The Irish laterites and bauxites were formed in two distinct stages : $(a)$ alteration to lithomarge, consisting of kaolinite or halloysite ; and $(b)$ lateritization, involving further desilication with formation of gibbsite $\left(\mathrm{Al}_{2} \mathrm{O}_{3} \cdot 3 \mathrm{H}_{2} \mathrm{O}\right)$ together with oxides of iron and titanium. With long-continued operation of the process the iron oxides tend to concentrate towards the surface, forming an increasingly ferruginous laterite and eventually a workable iron ore, overlying a layer of richly aluminous laterite or bauxite. In Ireland, unfortunately, neither complete desilication of lithomarge nor clean separation of aluminous from ferruginous laterite has occurred over more than

* The Composition and Origin of the Antrim Laterites and Bauxites. By V. A. Eyles, with mineral determinations by $X$-ray methods by F. A. Bannister (British Museum, Natural History) and G. W. Brindley and $\mathbf{J}$. Goodyear (University of Leeds). (Memoir of the Geological Survey of Northern Treland.) Pp. vi +90 . (Belfast: H.M. Stationery limited areas. The prevailing types are lateritic lithomarges and ferruginous or siliceous laterites. It appears that quartz, originally present in a parental roek, may persist unchanged; the possibility of, and the conditions governing, the total elimination of quartz still require further investigation. A chemical method, devised and described by Mr. C. O. Harvey, is given for the quantitative determination of quartz in the presence of combined silica.

Much valuable information has been obtained from the application of the X-ray diffraction technique to selected specimens. The chief minerals recognized include meta-halloysite and kaolinite; gibbsite and boehmite (but not dirspore); hæmatite, goethite and magnetite; and anatase. Chamosite has been found in certain parts of the laterite horizon which exhibit a greenish tinge. Since the formation of chamosite requires reducing conditions, its occurrence implies that it is a secondary mineral relative to the lateritic minerals with which it is now associated. The abundance and distribution of various minor elements has been determined by Dr. S. Landergren, whose results demonstrate enrichment of the laterites in vanadium and probably in chromium.

Discussing the geological conditions influencing the formation of the several hydrated oxides of aluminium, Mr. Eyles points out that the widespread distribution and prevalence of the gibbsite type of bauxite suggests that this is the variety normally developed. He presents detailed evidence to justify the tentative conclusions: "(i) that the formation of monohydrates in large amounts results from a change of geological environment superimposed on gibbsitic laterites after the formation of the latter; (ii) that increased pressure resulting from subsidence, or dynamic action, or both, and not rise in temperature alone, may often be the main, though possibly not the sole, factor causing the large-scale development of monohydrates of alumina; (iii) that while igneous intrusions or lava flows alone may cause localized development of boehmite in laterite deposits, pressure is probably essential for the formation of diaspore in large quantities".

Mr. Eyles and his colleagues have made this a model investigation of its kind. It is to be hoped that their lead will be followed, so that it may no longer be necessary to direct attention to the fact that "descriptions of foreign laterite are not always sufficiently complete to permit generalizations to be drawn from the facts presented". A. Holmes

\section{CARNEGIE TRUST FOR THE UNIVERSITIES OF SCOTLAND}

\section{ANNUAL REPORT FOR 1952-53}

THE fifty-second annual report of the Carnegie Trust for the Universities of Scotland, covering the academic year 1952-53*, deals with a period before the most recent regulations of the Scottish Education Department for the award of bursaries by Scottish education authorities became effective so far as the Trust is concerned; but the executive committee to the trustees points out that the amounts awarded in terms of these regulations constitute a

* The Carnegie Trust for the Universities of Scotland. Fifty-second Annual Report (for the Year 1952-53). Submitted by the Executive (Edinburgh : $T$ and 